\title{
PERAN PEMERINTAH DESA DALAM MENUNJANG PENDAPATAN MASYARAKAT PETANI JAGUNG DI DESA DULOHUPA KECAMATAN BOLIYOHUTO KABUPATEN GORONTALO
}

\author{
Muh. Firyal Akbar \\ Widya Kurniati Mohi \\ Universitas Muhammadiyah Gorontalo \\ email: firyalakbar@umgo.ac.id
}

\begin{abstract}
ABSTRAK
Penelitian ini dilakukan di kantor Desa Dulohupa Kecamatan Boliyohuto. Peran Pemerintah Desa dalam pemberdayaan masyarakat di Desa Dulohupa Kecamatan Boliyohuto Kabupaten Gorontalo, sangat penting untuk mendukung kondisi Desa ini karena sebagian besar masyarakat di Desa ini memiliki mata pencaharian sebagai petani jagung sehingga memungkinkan dalam kegiatan pemberdayaan tanaman jagung. Tujuan dari penelitian ini adalah untuk mengetahui dan menganalisis peran pemerintahan Desa serta faktor apa saja yang mendorong dan menghambat peran pemerintahan Desa dalam menunjang pendapatan masyarakat petani jagung di Desa Dulohupa Kecamatan Boliyohuto Kabupaten Gorontalo.Hasil penelitian menunjukkan bahwa pemerintah Desa Doluhupa memegang peranan penting untuk menentukan langkah yang tepat dalam meningkatkan pendapatan masyarakat petani jagung ataupun memberdayakan masyarakat di Desa Dulohupa Kecamatan Boliyohuto.
\end{abstract}

Kata Kunci: Peran Pemerintah, Pendapatan Masyarakat, Petani

\begin{abstract}
This research was conducted at the office of Dulohupa Village ofBoliyohuto District. The village government role in community development in the village Dulohupa Boliyohuto District of Gorontalo district, very important to support the conditions of this village because most of the people in this village have subsistence corn farmers so as to enable the empowerment of corn plants. The aims of this research were to determine and analyze the extent of countryside government and factors that encourage and inhibit the role of countryside government in supporting the income of corn farmer at Dulohupa village, Boliyohuto sub district of Gorontalo district. The results showed that the village government Doluhupa plays an important role to determine the appropriate steps to increase incomes of farmers' corn or empower the people in the village of the District Dulohupa Boliyohuto.
\end{abstract}

Keywords: Role of Government, Community Income, Farmers

Vol.3 No.2 


\section{PENDAHULUAN}

Pemerintah Desa sebagai ujung tombak dalam sistem Pemerintahan daerah akan berhubungan dan bersentuhan langsung dengan masyarakat. Karena itu, sistem dan mekanisme penyelenggaraan Pemerintahan daerah sangat didukung dan ditentukan oleh Pemerintah Desa dan Badan Permusyawaratan Desa (BPD) sebagai bagian dari Pemerintah Daerah. Struktur kelembagaan dan mekanisme kerja di semua tingkatan Pemerintah, khususnya Pemerintahan Desa harus diarahkan untuk dapat menciptakan Pemerintahan yang peka terhadap perkembangan dan perubahan yang terjadi dalam masyarakat.

Dalam

penyelenggaraan

Pemerintahan harus dipandang sebagai suatu proses multidimensional yang mencakup berbagai perubahan mendasar atas struktur sosial, sikap-sikap masyarakat dan institusi-institusi nasional, disamping tetap mengejar akselerasi peningkatan ekonomi masyarakat dalam pengentasan kemiskinan.

Peran Pemerintah dalam analisa sosial ekonomi ialah menciptakan tingkat ekonomi masyarakat yang bebas dari tekanan persaingan ekonomi menuju kemandirian. Tujuan ekonomi tersebut yang menjadi landasan untuk bertahan dalam era desentralisasi dan salah satu tantangan adalah pemberdayaan masyarakat menuju kemantapan ekonomi dari berbagai jenjang, manakala stabilitas ekonomi menjamin sebuah kekuatan ekonomi. Untuk itu yang sangat pasti mengakses sumber ekonomi yang lebih besar. Kekuatan yang mendasar dalam menjawab hal tersebut adalah bagaimana ekonomi masyarakat bawah bisa meningkat. Dari kondisi inilah memberdayakan masyarakat miskin adalah sebuah cara untuk memperhatikan aspek produktif, dengan tidak melalaikan spesifikasi keahlian sehingga masukan yang di distribusikan keusaha ekonomi bagi masyarakat kecil akan berhasil. Kita memahami bahwa peran Pemerintah sangat dibutuhkan dalam memecahkan berbagai masalah seperti kemiskinan, kesenjangan sosial, pengangguran, dsb. Namun pemahaman yang demikian tidak boleh dibiarkan begitu saja tanpa adanya kritik maupun kontrol terhadap masukan karena pada prinsipnya kehadiran Pemerintah dapat diasumsikan sebagai satusatunya cara untuk dapat memecahkan masalah dapat berbalik fakta, seperti adanya kesenjangan sosial ekonomi.

Bertitik tolak dari permasalahan tersebut, dibutuhkan keterlibatan aktif dan keseriusan dari Pemerintahan setempat baik Pemerintah pusat, Pemerintah daerah, kecamatan maupun Pemerintah Desa. Pemerintah juga harus melihat setiap kebijakan-kebijakan yang akan diimplementasikan atau yang akan dilaksanakan, baik itu berupa 
peraturan perundang-undangan, maupun melalui peraturan daerah yang akan dikeluarkan maupun yang akan dijalankan. Sedangkan masyarakat sendiri yang akan diposisikan untuk menilainya apakah kebijakan-kebijakan tersebut dapat dikatakan sebagai salah satu pemecahan masalah ataukah sebaliknya dapat menimbulkan masalah baru lagi dalam Pemerintahan tersebut.

Desa Dulohupa sampai saat ini masih melakukan pembangunan baik dari segi infrastruktur dan suprastruktur dan membenahi pelayanan publik yang masih tertinggal serta memberikan sumbangsih pikiran dan tenaga dalam program-program Pemerintah Desa. Syarat yang diperlukan untuk menunjukkan tingginya tingkat keberhasilan pertumbuhan ekonomi yang dilaksanakan oleh Pemerintah Desa adalah adanya peningkatan pendapatan ekonomi masyarakat sehingga berdampak pada peningkatan tingkat kesejahteraan masyarakat.

Persoalan yang dihadapi di Desa Dulohupa Kecamatan Boliyohuto Kabupaten Gorontalo adalah peran Pemerintah Desa dalam pemberdayaan masyarakat belum dilaksanakan secara maksimal. Hal ini tampak dalam pemberdayaan masyarakat petani jagung. Padahal di Desa ini jagung merupakan komoditi utaman petani yang layak ditingkatkan karena wilayah tofografi
Desa yang sangat cocok dengan jenis tanaman jagung.

Peran Pemerintah Desa dalam pembedayaan masyarakat petani jagung sangat perlu mendapat perhatian sebagai salah satu program agropolitan dalam meningkatkan kesejahteraan masyarakat terutama karena belum tampak. Pemerintah belum mengupayakan pemberdaayaan baik dalam penyuluhan tata cara penanaman jagung yang baik, penyediaan bibit pupuk dan pestisida maupun mengatur pemasaran jagung yang dapat memberdayakan petani jagung tersebut.

Peran Pemerintah Desa dalam pemberdayaan masyarakat di Desa Dulohupa Kecamatan Boliyohuto Kabupaten Gorontalo, sangat penting untuk mendukung kondisi Desa ini karena sebagian besar masyarakat di Desa ini memiliki mata pencaharian sebagai petani jagung sehingga memungkinkan dalam kegiatan pemberdayaan tanaman jagung.

Perawatan tanaman jagung dilakukan masyarakat secara alami dan tidak menggunakan pupuk dan pestisida yang optimal. Hal ini karena sulitnya mendapatkan pupuk dan pestisida. Sebagian pupuk dan pestisida dijual pula ditoko-toko terdekat tetapi dengan harga yang terlampau mahal. Hal ini berdampak pada hasil panen jagung tidak sesuai dengan harapan.

Berdasarkan uraian permasalahan tersebut, diperlukan upaya 
Pemerintah Desa yang optimal dalam pemberdayaan masyarakat petani jagung yang dapat memberikan kontribusi dalam peningkatan kesejahteraan masyarakat di Desa Dulohupa Kecamatan Boliyohuto Kabupaten Gorontalo.

Berdasarkan latar belakang di atas, maka penulis bermaksud untuk melakukan penelitian dengan judul "Peran Pemerintahan Desa Dalam Menunjang Pendapatan Masyarakat Petani Jagung di Desa Dulohupa Kecamatan Boliyohuto Kabupaten Gorontalo". Adapun yang menjadi fokus masalah dalam penelitian ini adalah Bagaimana peran Pemerintah Desa dalam menunjang pendapatan masyarakat Petani Jagung di Desa Dulohupa Kecamatan Boliyohuto Kabupaten Gorontalo.

\section{METODE PENELITIAN}

\section{Pendekatan Dan Jenis \\ Penelitian}

Pendekatan yang digunakan adalah fenomenologis. Menurut Moleong (2001:1) bahwa : "Pendekatan fenomenologis dalam penelitian kualitatif berusaha untuk memahami arti peristiwa dan kaitannya terhadap orang-orang biasa dalam situasi tertentu. Digunakan pendekatan kualitatif karena adanya kesesuaian antara kerakteristik dan ciri-ciri yang cocok, diantaranya : (1) instrumen utamanya adalah Pemerintah Desa, (2) bersifat deskritif, (3) kerja lapangan, (4) holistic. Jenis penelitian yang digunakan adalah pendekatan kualitatif dengan pendekatan ini bersifat interpretatif untuk memahami makna dan tafsiran yang tersimpan dalam niat pelakunya. Desain pengukuran, analisis dan laporan penelitian didasarkan pada tujuan penelitian yang ditekankan pada makna peran Kepala Desa dalam menunjang pendapatan ekonomi masyarakat serta keberhasilan pembangunan.

\section{Lokasi Penelitian}

Penelitian ini dilaksanakan di Desa Dulohupa Kecamatan Boliyohuto Kabupaten Gorontalo, dan direncanakan alokasi waktu dalam penelitian ini selama 3 (tiga) bulan. Terhitung sejak pelaksanaan studi Pendahuluan sampai dengan selesai proses pembimbingan dalam menyusun laporan hasil penelitian.

\section{Sumber Data}

Dalam mengumpulkan data, peneliti menetapkan beberapa sumber data sebagai berikut :

1. Data primer yaitu data langsung tentang informasi dari Kepala Desa, Ketua BPD, Ketua LPM, tokoh masyarakat, tokoh agama yang ada di wilayah Desa Dulohupa Kecamatan Boliyohuto.

2. Sumber sekunder, yaitu sumber data yang diperoleh dari penelitian kepustakaan, dokumentasi, literatur atau referensi yang ada kaitannya dengan masalah yang dikaji dalam penelitian. 
3. Prosedur Pengumpulan dan Analisis Data

Perekaman data dalam penelitian ini adalah melakukan wawancara, studi dokementasi, observasi lapangan, dan pengamatan.

Teknik analisis data yang digunakan dalam penelitian ini adalah analisis kualitatif, yaitu proses analisis dimulai dengan menelaah dan mengkaji seluruh data yang diperoleh dari berbagai sumber yang terkait.

\section{HASIL DAN PEMBAHASAN}

\section{Gambaran Umum Lokasi Penelitian}

Desa Dulohupa merupakan salah satu Desa dari 13 Desa di Kecamatan Boliyohuto Kabupaten Gorontalo. Desa ini berdiri sejak akhir Tahun 2010 sesuai Peraturan Daerah Kabupaten Gorontalo Nomor: 06 Tahun 1998 Tentang Pembentukan Desa. Desa Dulohupa sebagai pemekaran gabungan dari Desa Parungi dan Desa Motoduto Kecamatan Boliyohuto.

Luas wilayah Desa Dulohupa adalah 1.675.075 Ha Wilayah Desa Dulohupa meliputi atas areal tanah persawahan seluas $10 \mathrm{Ha}$, lahan perkebunan jagung seluas 1.565.075 $\mathrm{Ha}$ dan lainnya seluas $100 \mathrm{Ha}$. Pemukiman masyarakat menyebar pada lahan persawahan dan perkebunan jagung yang merupakan mata pencaharian utama masyarakat Desa Dulohupa Kecamatan Boliohuto Kabupaten Gorontalo.
Wilayah Desa Dulohupa secara geografis berada di $0^{\circ} 41,29^{\circ}$ Lintang Utara dan $122^{\circ} 37,21$ Bujur timur. Dilihat dari topografi ketinggian wilayah Desa Dulohupa berada pada $36 \mathrm{~m}$ dari permukaan air laut dengan curah hujan rata-rata $20 \mathrm{~mm} /$ tahun, serta suhu rata-rata pertahun adalah $30^{\circ}$ dengan kelembaban udara ratarata $70 \%$ per tahun. Wilayah Desa Dulohupa Kecamatan Boliyohuto Kabupaten Gorontalo, terletak pada bagian barat Kabupaten Gorontalo dengan batas-batas yakni sebelah utara berbatasan dengan Desa Iloheluma, Sebelah Selatan berbatasan dengan Desa Suka Damai, sebelah Timur berbatasan dengan Desa Parungi dan sebelah Barat berbatasan dengan Desa Motoduto.

Desa Dulohupa Kecamatan Boliyohuto Kabupaten Gorontalo, secara administratif membawahi 2 Dusun yaitu Dusun Pone dan Dusun Gelora. Jumlah penduduk di Desa Dulohupa Kecamatan Boliyohuto Kabupaten Gorontalo tahun 2015 berjumlah 537 jiwa yakni penduduk laki-laki berjumlah 273 jiwa dan penduduk perempuan berjumlah 264 jiwa. Sedangkan jumlah Kepala Keluarga sebanyak 150 KK. Mata pencaharian penduduk sebagian besar adalah petani jagung dan sisanya adalah petani sawah, wiraswasta, buruh tani, buruh pabrik gula, buruh pabrik tepung kelapa dan PNS.

Pembahasan

Studi ini dilaksanakan di Desa Dulohupa Kecamatan Boliyohuto 
Kabupaten Gorontalo, yang tentunya memiliki program-program Desa yang bertujuan meningkatkan pendapatan ekonomi masyarakatnya atau dengan kata lain memajukan Desa serta meningkatkan pendapatan masyarakatnya. Dalam proses pengumpulan data di penelitian ini, melalui studi kepustakaan peneliti juga melakukan observasi serta interview (wawancara) kepada beberapa informan. Interview (wawancara) kepada informan dilakukan agar penulis mendapatkan informasi yang valid mengenai persoalan yang diteliti dari informan yang memiliki kompetensi mengenai peran Pemerintah dalam peningkatan pendapatan ekonomi masyarakat di Desa Dulohupa.

Pada awalnya informan yang ditentukan dalam penelitian ini adalah Kepala Desa Dulohupa, ketua BPD Desa Dulohupa, 10 orang masyrakat. Namun, sejalan dengan studi dan kebutuhan informasi penulis, informan dalam penelitian ini bertambah dari sebelumnya, informan ini merupakan pihak-pihak terkait dalam peningkatan ekonomi masyarakat Desa itu sendiri. Dalam melaksanakan interview (wawancara), sebagai instrumen peneliti menggunakan pedoman wawancara yang disusun berdasarkan fokus penelitian yang telah ditetapkan sebelumnya. Pedoman wawancara ini terdiri dari pertanyaan-pertanyaan yang bersifat umum dan pertanyaan yang sifatnya mendetail. Hal ini dilakukan agar peneliti dapat menghasilkan data yang akurat serta lengkap akan informasi yang dibutuhkan dalam studi ini.

\section{Peran Pemerintahan Desa dalam Meningkatkan Pendapatan Masyarakat Petani Jagung}

Peran Pemerintah dalam meningkatkan pendapatan petani jagung di Desa Dulohupa Kecamatan Boliyohuto Kabupaten Gorontalo dibahas melalui indikator-indikator yaitu peran dalam sosialisasi tata cara penanaman jagung, peran dalam penyediaan bibit, pupuk dan pestisida dan peran dalam membantu pemasaran hasil panen.

1. Peran Pemerintah dalam
sosialisasi tata cara penanaman
jagung

Peran Pemerintah Desa Dulohupa Kecamatan Boliyohuto Kabupaten Gorontalo dalam sosialisasi tata cara penanaman jagung dilakukan dengan cara sosialisasi tentang jenis-jenis bibit jagung sehingga masyarakat petani jagung dapat memilih jenis bibit jagung yang baik untuk ditanam, Di samping itu dilakukan pula sosialisasi teknik khusus penanaman jagung dan pemeliharaan tanaman jagung yang baik bagi masyarakat petani jagung.

$$
\text { Kegiatan }
$$
sosialisasi dilaksanakan sebanyak 4 kali dalam setahun bulan sekali yaitu pada awal musim tanam yaitu di Kantor Desa Dulohupa Kecamatan Boliyohuto 
Kabupaten Gorontalo. Pelaksanaan sosialisasi dilaksanakan oleh aparat Pemerintah Desa mulai dari Kepala Desa, Sekretaris Desa serta para Kepala Urusan Desa dan bekerja sama dengan balai pertanian setempat.

Proses pelaksanaan sosialisasi dimulai dengan mengirimkan surat permohonan kepada Balai Pertanian setempat dan kemudian berdasarkan surat balasan kesediaan penyuluh pertanian aparat Pemerintah Desa menghubungi para kepala dusun untuk memberitahukan kepada masyarakat petani. Pada pelaksanaan sosialisasi dan seluruh kegiatan ditanggung oleh aparat Pemerintah Desa sedangkan balai pertanian setempat hanya mengadakan tenaga penyuluh.

Berdasarkan deskripsi di atas tampak bahwa peran Pemerintah Desa Dulohupa dalam pemberdayaan masyarakat petani telah dilaksanakan melalui program kinerja Desa sebagai wujud kepedulian kepada masyarakat petani jagung di Desa Dulohupa Kecamatan Boliyohuto Kabupaten Gorontalo. Sebagaimana hasil wawancara dengan Kepala Desa Dulohupa Kecamatan Boliyohuto Kabupaten Gorontalo (HK, 40 Tahun) dijelaskan sebagai berikut:

"Sebagai Kepala Desa saya sangat bertanggung jawab dalam peran untuk menunjang pendapatan masyarakat petani jagung di Desa Dulohupa. Peran Pemerintah Desa dalam sosialisasi diawali dengan pemilihan lahan yang baik untuk jagung, kemudian sosialisasi pemilihan bibit jagung yang sesuai. Walaupun tenaga penyuluh kami datangkan dari Balai Pertanian setempat, namun pelaksanaan sepenuhnya diatur oleh aparat Pemerintah Desa mulai dari menghubungi masyarakat, menyiapkan admnistrasi bahkan mengadakan konsumsi. Namun kegiatan tersebut sampai saat ini masih diprogramkan dalam 4 kali dalam setahun Kriteria lahan, bibit dan pupuk serta cara perawatan semua diberikan dalam sosialisasi oleh penyuluh pertanian" (Hasil Wawancara, 15 September)

Berdasarkan hasil wawancara di atas peneliti berpendapat bahwa peran Pemerintah Desa Dulohupa Kecamatan Boliyohuto Kabupaten Gorontalo, telah dilaksanakan dengan baik, walaupun dalam rentang satu kali musim tanam. Kepala Desa merasa bertanggung jawab dalam peran untuk meningkatkan ekonomi masyarakat petani jagung sehingga pelaksanaan sosialisasi dilakukan dengan cara pemilihan lahan yang baik untuk jagung, kemudian sosialisasi pemilihan bibit jagung yang sesuai oleh tenaga penyuluh dari balai pertanian setempat.

Untuk kelancaran kegiatan sosialisasi tata cara penanaman jagung kepadamasyarakat petani jagung di Desa Dulohupa Kecamatan Boliyohuto, di samping Kepala Desa, aparat Pemerintah Desa lainnya 
memberikan kontribusi dalam membantu Kepala Desa. Hal ini sebagaimana hasil wawancara dengan Sekretaris Desa Dulohupa, Kecamatan Boliyohuto Kabupaten Gorontalo (LH, 25 tahun) menjelaskan sebagai berikut:

"Walaupun kegiatan sosialisasi ini dilaksanakan langsung oleh tenaga penyuluh pertanian, tetapi peran kami di Desa yaitu mendatangkan tenaga penyuluh tersebut. Sebagai sekertaris Desa peran saya terutama menyiapkan surat permohonan ke Dinas Petani setempat, kemudian mengecek kesediaan penyuluh pertanian. saya membuat surat untuk pada Kepala Dusun untuk diteruskan secara lisan maupun tulisan kepada masyarakat petani agar hadir dalam kegiatan penyuluhan. Di samping itu pada acara sosialisasi saya bertugas menyiapkan seluruh acara serta menentukan tempat pelaksanaan sosialisasi" (Hasil Wawancara, 15 September 2015)

Berdasarkan hasil wawancara di atas tampak Sekertaris Desa Dulohupa Kecamatan Boliyohuto Kabupaten Gorontalo yang merupakan salah satu perangkat Desa telah memberikan peran nyata dalam kegiatan sosialisasi tata cara penanaman jagung. Peran Sekertaris Desa tersebut diantaranya menyiapkan surat permohonan, mengecek kesediaan penyuluh, membuat surat untuk pada Kepala Dusun serta menyiapkan seluruh acara dan menentukan tempat pelaksanaan kegiatan sosialisasi.

Pelaksanaan

kegiatan

sosialisasi yang dilaksanakan diikuti oleh sebagian besar masyarakat petani jagung yaitu lebih dari $70 \%$. Jika ada mayarakat petani jagung yang tidak hadir maka Kepala Dusun bertugas memberikan ararahan untuk hadir pada pertemuan-pertemuan berikutnya. Antusias masyarakat dapat di lihat pula pada banyaknya masyarakat yang bertanya kepada para penyuluh lapangan tentang materi yang dibahas.

\section{Peran Pemerintah dalam penyediaan Bibit, pupuk dan Pestisida}

Peran Pemerintah Desa Dulohupa Kecamatan Boliyohuto Kabupaten Gorontalo dalam penyediaan bibit, pupuk dan pestisida belum dapat dilaksanakan oleh aparat Pemerintah Desa. Hal ini terlihat dari belum adanya bibit, pupuk maupun pestisida yang disediakan di Desa ini. Sebagian besar masyarakat petani jagung harus membeli bibit, pupuk maupun pestisida harus ke Kota Gorontalo yang jaraknya sekitar 60 kilo meter dari Desa Dulohupa.

Di samping itu pula terdapat masyarakat petani jagung yang terpaksa membeli bibit jagung, pupuk dan pestisida dari kios-kios milik masyarakat di Desa tetangga, seperti di Desa Sidomulyo dan Desa Sidodadi dengan harga yang relative mahal dari harga-harga yang ditentukan Pemerintah. Khusus untuk 
pupuk subsidi di Desa Dulohupa masih sangat kurang dan banyak pupuk bersubsidi hanya diperuntukkan untuk petani sawah. Hal ini berarti perhatian Pemerintah dalam penyediaan bibit, pupuk dan pesetisida belum diperhatikan dengan baik. Keadaan tersebut, ketika dikonfirmasikan kepada Kepala Desa Dulohupa Kecamatan Boliyohuto Kabupaten Gorontalo (HK, 40 Tahun) dijelaskan sebagai berikut:

"Sangat berat hati kami katakan bahwa peran dalam penyediaan bibit jagung, pupuk dan pestisida belum dapat kami laksanakan.Alasan kami memang cukup masuk akal karena peran tersebut memerlukan modal karena ini mencakup masalah penyediaan dan pengadaan barang. Permasalahan ini sudah pernah diungkapkan oleh masyarakat petani jagung pada kami tetapi sampai saat ini kami belum melakukan koordinasi dengan atasan karena kesibukan mengurus kegiatan lain. Beberapa waktu lalu kami telah menyiapkan proposal dan memohon petunujuk kepada atasan (Camat,) namun sampai saat ini kegiatan tersebut belum terealisasi” (Hasil Wawancara, 19 September 2015)

Berdasarkan hasil wawancara tersebut dapat disimpulkan bahwa peran Pemerintah Desa Dulohupa Kecamatan Boliohuto Kabupaten Gorontalo dalam penyediaan bibit jagung, pupuk dan pestisida belum dilaksanakan. Kepala Desa beserta aparat pemeritah Desa lainnya belum mengupayakan penyediaan bibit jagung, pupuk dan pestisida yang dapat memudahkan masyarakat petani jagung. Keadaan ini, jelas mengakibatkan masyarakat petani jagung menemui kesulitan dalam mencari bibit jagung yang baik untuk ditanam. Keadaan ini seiring yang di kemukakan oleh seorang masyarakat petani jagung dari Dusun Pone (JR, 38 tahun) sebagai berikut"

"Memang benar. Di Desa ini kami sangat kesulitan mencari bibit jagung yang baik. Kendati ada hanya di kios-kios di Desa tentangga dengan harga yang sangat mahal, karena pedagang itu jelas mencari keuntungan yang tinggi. Di kota juga ada (Kota Gorontalo, peneliti) tetapi kami harus menyewa mobil pergi pulang. Hal ini berakibat perawatan jagung yang kami tanam tidak dapat dilakuka dengan baik. Apalagi kalau ada musim penyakit jagung, terpaksa kami bersabar saja karena mahalnya pestisida untuk menyomprot penyakit tanaman jagung dan pada akhirnya panen jagung tidak berhasil sesuai yang kami harapkan" (Hasil Wawancara, 21 September 2015)

Berdasarkan hasil wawancara tersebut dapat disimpulkan bahwa masyarakat petani jagung di Desa Dulohupa Kecamatan Boliyohuto Kabupaten Gorontalo, sangat kesulitan mencari bibit jagung yang baik. Terdapat pula bibit jagung, pupuk dan pestisida di kios-kios di Desa tentangga tetapi sangat mahal 
harganya. Sebagian masyarakat petani jagu terpaksa menyewa mobil ke Kota Gorontalo untuk membeli bibit jagung, pupuk dan pestisida dan hal ini mengakibatkan biaya penanaman jagung menjadi mahal.

\section{Peran dalam Membantu Pemasaran Hasil Panen}

Salah satu peran Pemerintah Desa yang sangat penting dalam pemberdayaan masyarakat petani jagung adalah membantu pemasaran hasil panen jagung. Di Desa Dulohupa Kecamatan Boliyohuto Kabupaten Gorontalo peran dalam membantu pemasaran hasil jagung belum dapat dilaksanakan dengan baik. Dalam hal ini Pemerintah Desa belum dapat mengupayakan agar petani tidak sembarang menjual hasil panennya.

Berdasarkan pengamatan bahwa hasil panen petani dibeli oleh tengkulak dan para pedagang yang tergolong pengusaha perdagangan , sehingga harga murah yaitu $\mathrm{Rp}$. 2000,-untuk jagung basah dan Rp 2500,-yang kering. Nyatanya tidak sesuai yang ditentukan oleh Pemerintah Propinsi yaitu Rp. 2700,untuk jagung basah dan Rp. 3.000,yang kering. Bahkan sebagian petani terlanjur ikat kontrak dengan para tengkulak yang mengambil keuntungan yang lebih dengan cara memberikan uang sebelum tanaman jagung di panen. Hal ini mengakibatkan harga jagung sangat rendah.
Pemerintah Desa Dulohupa Kecamatan Boliohuto Kabupaten Gorontalo berdasarkan konfirmasi mengaku permasalahan ini. Berdasarkan hasil wawancara dengan Kepala Desa Dulohupa Kecamatan Boliyohuto Kabupaten Gorontalo (HK, 40 Tahun) dijelaskan sebagai berikut:

"Memang benar kami aparat Desa belum dapat mengontrol harga jagung yang dijual petani. Hal ini karena sebagian besar petani sudah belangganan dengan para pedagang. Para pedagang tersebut telah menyediakan truck-truck pengangkut sampai di lahan tanaman jagung dan mereka membeli jagung dengan harga yang murah tetapi dijual digudang-gudang Kota Gorontalo dengan harga yang mahal. Upaya yang telah kami lakukan sekedar memberitahukan harga normal yang ditentukan oleh pemeritah daerah kepada petani, namun karena petani kesulitan mengangkut hasil panen sampai ke gudang Gorontalo terpaksa dijual ke pedagang dan tengkulak. Kami tidak memiliki dana untuk membantu membeli jagung petani serta menyediakan truck-truck pengakut karena keterbatasan dana" (Hasil Wawancara, 21 september 2015)

Berdasarkan hasil wawancara tersebut menunjukkan belum ada peran pemerinrah Desa Dulohupa kecamatan Boliyohuto dalam membantu pemeliharaan hasil panen jagung. Pemerinrtah berdalih bahwa 
peran tersebut memerlukan dukungan dana karena Pemerintah harus menampung hasil panen jagung petani kemudian diagkut ke gudanggudang di Kota Gorontalo. Upaya Pemerintah sekedar memberitahukan harga jagung normal yang ditentukan oleh Pemerintah daerah kepada petani jagung tetapi hal ini tidak mampu mengendalikan harga jagung di Desa tersebut. Sikap aparat Pemerintah tentang permasalahan pemasaran jagung masyarakat belum dilakukan. Hal ini tampak pada sikap aparat yang tidak berupaya untuk meminta bantuan dari pemerinrah Provinsi untuk membantu pemasaran hasil panen jagung karena jika masalah ini dibiarkan akan berdampak pada hilangnya motivasi masyarakat dalam menanam jagung sebagai mata pencaharian.

\section{Peran Pemerintahan Desa dalam Memberdayakan Masyarakat Petani Jagung di Desa Dulohupa}

Wujud peran Pemerintah Desa Dulohupa Kecamatan Boliyohuto dalam pemberdayaan masyarakat petani jagung dapat dilihat dari beberapa aspek yaitu meningkatnya pendapatan masyarakat petani jagung, meningkatnya hasil panen jagung dan meningkatnya kebutuhan ekonomi keluarga. Berdasarkan hasil penelitian secara umum peran Pemerintah Desa dalam meningkatkan pendapatan ekonomi masyarakat petani jagung belum memberikan hasil yang optimal. Keadaan tersebut akan dijelaskan sesuai dengan aspek-aspek pemberdayaan sebagai berikut:

a. Peningkatan pendapatan masyarakat petani jagung

Kurangnya peningkatan pendapatan ekonomi masyarakat petani di Desa Dulohupa diakibatkan oleh beberapa hal, sebagaimana wawancara dengan seorang petani dari Dusun Pone yaitu (SI, 45 tahun) dijelaskan sebagai berikut:

"Lahan kosong di Desa ini memang masih banyak yang dapat diolah tetapi minat masyarakat untuk mengolah lahan pertanian menjadi lahan jagung masih sangat kurang. Hal ini diakbatkan oleh semakin sulitnya mendapatkan bibit jagung yang baik. Di samping itu sulitnya mendapatkan pupuk dan pestisda dalam perawatan jagung membuat masyarakat lebih baik bertanam tanaman lain seperti palawija, sayur mayur serta tomat yang lebih mudah perawatannya" (Hasil Wawancara, 21 September 2015)

Berdasarkan hasil wawancara tersebut dapat tampak tidak meningkatnya jumlah masyarakat petani jagung diakibatkan oleh semakin sulitnya mendapatkan bibit jagung yang baik. Kesulitan yang dihadapi petani jagung tersebut membuat petani lain lebih baik menanam tanaman lain yang lebih mudah untuk ditanam dan dirawat.

Penyebab lain dari kurang meningkatnya jumlah petani jagung 
di Desa Dulohupa. Kecamatan Boliyohuto Kabupaten Gorontalo karena kurangnya peran Pemerintah dalam memberikan motivasi bagi petani jagung terutama penyediaan bibit tanaman jagung, pupuk dan pestisida sehingga masyarakat petai jagung tidak termotivasi dalam mengusahakan lahan pertani jagung. Menurut Ketua BPD Desa Dulohupa Kecamatan Boliyohuto Kabupaten Gorontalo (SN,42 Tahun) dijelaskan sebagai berikut:

"Kurang meningkatkan jumlah pendapatan petani di Desa ini bukan saja diakibatkan oleh kesulitan mencari bibit, pupuk dan pestisida, tetapi sebagian karena kurang minatnya keluarga petani terhadap pertanian. Di Desa ini banyak petani yang memiliki anak yang sedang sekolah bahkan kuliah tetapi anaknya tersebut tidak berminat pada pertanian karena menganggap sekolahnya tidak cocok untuk pertanian sehingga banyak anakanak petani menjadi pegawai dan karyawan di perusahaan seperti Pabrik Gula yang berjarak sekitar 18 kilo meter dan juga pabrik tepung kelapa yang jaraknya 2 kilo meter dari Desa ini, bahkan sudah dibuka lagi perusahaan kelapa sawit yang ada di kecamatan tetangga yaitu di kecamatan Wonosari" (Hasil Wawancara, 23 september 2015)

Berdasarkan hasil wawancara di atas tampak bahwa kurang meningkatnya Pendapatan petani di Desa Dulohupa Kecamatan
Boliyohuto Kabupaten Gorontalo, disamping diakibatkan oleh kesulitan mencari bibit, pupuk dan pestisida, tetapi sebagian pula diakibatkan karena kurang minatnya keluarga petani terhadap pertanian. Sebagian anak-anak petani menjadi pegawai dan karyawan di perusahaanperusahaan.

\section{b. Luasan Ladang Jagung}

Berdasarkan data yang dihimpun, lahan petani jagung di Desa Dulohupa Kecamatan Boliyohuto Kabupaten Gorontalo Tahun 2015 yaitu Dusun Pone 55 Hektar, dan Dusun Pone sebanyak 57,5 Hektar (Kantor Desa Dulohupa). Berdasarkan data tersebut dilakukan wawancara dengan Kepala Desa Dulohupa Kecamatan Boliyohuto Kabupaten Gorontalo (HK, 40 Tahun) dijelaskan sebagai berikut:

"Berkurangnya lahan pertanian jagung bukan saja diakibatkan oleh kurangnya peran aparat Pemerintah Desa, tetapi karena banyak lahan pertanian jagung dialihfungsikan untuk menanam tanaman lain, misalnya dijadikan lahan persawahan, ditanami sayuran dan palawija. Di samping terdapat lahan jagung yang ada dipinggir jalan dijadikan pemukiman oleh warga dan dijual kepada pihak lain menjadi tempat mendirikan kios dan toko bahkan sekarang ini ada warga yang telah menjual lahan pertaniannya kepada perusahaan seperti kelapa sawit. 
(Hasil Wawancara, 21 september 2015)

Berdasarkan hasil wawancara tersebut tampak bahwa penyebab utama kurangnya peningkatan luasan lahan perkebunan jagung diakibatkan oleh alih fungsi lahan jagung untuk tanaman lain seperti palawija dan sayur-sayuran. Disamping terdapat lahan jagung yang ada dipinggir jalan dijadikan pemukiman oleh warga dan jadi lahan bisnis lain.

\section{c. Hasil panen jagung}

Sasaran akhir dari kegiatan pertanian jagung oleh petani adalah hasil panen jagung. Di Desa Dulohupa hasil panen jagung belum mengalami peningkatan setiap tahunnya. Hal ini diakibatkan oleh kurang perawatan yang baik terhadap tanaman jagung maupun adanya jenis tanah di Desa ini yang tidak ditanami lagi dengan tanaman jagung sehingga mengurangi hasil panen jagung. Sebagian petani melakukan perawatan tanaman jagung secara manual tanpa menggunakan pupuk maupun pestisida. Hasil panen tanaman jagung di Desa Dulohupa yaitu pada Tahun 2011 sebanyak 8 ton, tahun 2012 sebanyak 13 ton dan pada tahun 2013 sebanyak 12 ton (Kantor Desa Dulohupa/data Hasil Panen 2013).

Peningkatan hasil pertanian ini merupakan peluang bagi masyarakat dan aparat Pemerintah Desa Dulohupa Kecamatan Boliyohuto Kabupaten Gorontalo dalam meningkatkan peran dalam meningkatkan hasil panen jagung. Tanaman jagung dapat upayakan sebagai sumber pencaharian petani yang perlu dukungan dan peran Pemerintah sehingga memberikan kontribusi dalam peningkatan ekonomi masyarakat.

\section{d. Kebutuhan \\ Keluarga}

Ekonomi

Salah satu indikator kemajuan masyarakat adalah meningkatnya kebutuhan ekonomi keluarga. Di Desa Dulohupa Kecamatan Boliyohuto Kabupaten Gorontalo, tergolong pada masyarakat yang belum memperlihatkan peningkatan kebutuhan ekonomi yang optimal. Hal ini tampak pada animo beli keluarga yang masih sangat rendah. Beberapa indikator yang tampak di antaranya masih rendahnya animo beli terhadap kendaraan bermotor dan barang-barang eletronik pada setiap keluarga.

Berdasarkan hasil wawancara dengan masyarakat Desa Dulohupa (YA, 45 Tahun) dijelaskan bahwa:

"Di Desa ini jika hasil panen jagung banyak digunakan oleh petani untuk menyekolahkan anaknya. Sebagian pula ada yang membeli benda electronic dan kendaraan bermotor, tetapi hanya sebagian kecil. Jika panen jagung berhasil dengan baik maka kami gunakan hasil tersebut untuk membeli kebutuhan ekonomi yang lebih 
penting (Hasil Wawancara, 19 September 2015)

Berdasarkan hasil wawancara di atas dapat disimpulkan bahwa hasil panen petani jagung tidak mencukupi kebutuhan dan meningkatkan ekonomi bagi masyarakat. Semakin baik hasil panen semakin meningkat pula kebutuhan ekonomi keluarga. Hasil panen yang baik meningkatkan kebutuhan ekonomi keluarga seperti membeli benda electronik seperti televisi, video dan kendaraan bermotor. Hanya sebagian kecil masyarakat petani jagung di Desa Dulohupa belum memiliki kendaraan motor roda dua maupun roda empat.

\section{Faktor Pendukung dan Penghambat Peran Pemerintahan Desa dalam Meningkatkan Ekonomi Masyarakat Petani \\ Setiap kegiatan memiliki faktor} pendukung dan penghambat. Demikian pula dengan peran Pemerintah dalam meningkatkan pendapatan petani jagung di Desa Dulohupa Kecamatan Boliyohuto Kabupaten Gorontalo. Secara rinci faktor pendukung dan penghambat tersebut akan diuraikan sebagai berikut:

\section{a. Peran Pemerintah dalam Sosialisasi Tata Cara Penanaman Jagung}

Dari hasil penelitian didapatkan bahwa faktor yang mendukung peran Pemerintah Desa Dulohupa Kecamatan Boliyohuto Kabupaten
Gorontalo dalam sosialisasi tata cara penanaman jagung sebagai berikut: Faktor Pendukung yakni hubungan dan kerja sama yang baik antara Penyuluh dan aparat Pemerintah Desa, Antusias masyarakat petani jagung dalam mengikuti sosialisasi yang di laksanakan serta gedung pertemuan yang siap dan mendukung kegiatan. Faktor Penghambat yakni kurang koordinasi aparat Pemerintah kepada Dinas Penyuluh Pertanian, masyarakat yang tidak menyadari dan apatis terhadap kegiatan penyuluhan serta tidak adanya sarana dan prasarana.

b. Peran Pemerintah dalam penyediaan Bibit, Pupuk dan Pestisida

Dari hasil pemnelitian didapatkan bahwa faktor Pendukung yakni pemberian modal dari Pemerintah daerah ke Pemerintah Desa dalam menyediakan alat bahan, Kesadaran masyarakat petani jagung dalam mendirikan Koperasi serba usaha serta dukungan pihak swasta dalam membangun Toko dan Kios Saprodi di lingkungan Desa. Faktor Penghambat yakni kurangnya kesadaran masyarakat dalam menggunakan perawatan jagung karena masih bersifat manual, tidak ada upaya dalam mendirikan Koperasi penyediaan bibit, pupuk dan pestisida serta tidak ada dukungan pihak ke tiga dalam menyediakan sarana dan prasarana penyediaan alat dan bahan pertanian. 
c. Peran Pemerintah dalam Membantu

Pemasaran

Hasil Panen

Dari hasil penelitian didapatkan bahwa faktor Pendukung yakni kesadaran petani tidak menjual hasil panen kepada para tengkulak, kepedulian Pemerintah Provinsi untuk menjemput langsung hasil panen di lokasi ladang. Faktor Penghambat yakni masyarakat yang menjual hasil panen kepada para tengkulak serta tidak adanya kepedulian Pemerintah Provinsi untuk menjemput langsung hasil panen di lokasi ladang.

\section{KESIMPULAN}

Berdasarkan hasil penelitian dan pembahasan di atas dapat disimpulkan bahwa peran Pemerintah Desa dalam pemberdayaan masyarakat petani jagung di Desa Dulohupa Kecamatan Boliyohuto, Kabupaten Gorontalo belum dilaksanakan secara optimal. Terdapat beberapa peran yang telah dilaksanakan dengan baik tetapi aspek lain belum terlaksana sesuai yang diharapkan. Peran Pemerintah Desa Dulohupa yang telah di laksanakan yakni:

- Mendatangkan penyuluh pertanian dengan melakukan sosialisasi tata cara penanaman jagung, tetapi masih terdapat aspekaspek yang perlu diperhatikan di antaranya perlu rentang waktu pelaksanaan sosialisasi dan bentuk sosialisasi dalam bentuk kebun percontohan yang dilaksanakan oleh aparat Pemerintah Desa.

Peran Pemerintah dalam penyediaan bibit jagung, pupuk dan pestisida belum dilaksanakan. Pemerintah Desa belum mengupayakan penyediaan bibit, pupuk maupun pestisida sehingga sebagian besar masyarakat petani jagung harus membeli bibit, pupuk maupun pestisida harus ke Kota Gorontalo.

Peran Pemerintah dalam Membantu Pemasaran Hasil Panen juga belum dilaksanakan dengan baik. Dalam hal ini Pemerintah Desa belum dapat mengupayakan agar petani tidak sembarang menjual hasil panennya. Peran pemerinrah Desa Dulohupa kecamatan Boliyohuto dalam membantu pemasaran hasil panen jagung belum tampak. Pemerintah berdalih bahwa peran tersebut memerlukan dukungan dana yang cukup besar karena Pemerintah harus menampung hasil panen jagung petani.

- Peran Pemerintah Desa dalam pemberdayaan masyarakat petani jagung di Desa Dulohupa Kecamatan Boliyohuto Kabupaten Gorontalo memiliki faktor pendukung dan faktor penghambat. Faktor pendukung di antaranya dukungan dan kepedulian Pemerintah dalam memberikan penyuluhan, penyediaan bibit pupuk dan pestisida maupun dukungan pemasaran hasil penen jagung. Sedangkan faktor penghambat 
terdapat pada kurangnya kepedulian masyarakat dalam mengikuti sosialisasi, tidak ada dukungan pihak ketiga dalam menyediakan sarana dan prasarana penyediaan alat dan bahan pertanian, serta kebiasaan masyarakat menjual hasil panen pada tengkulak.

\section{DAFTAR PUSTAKA}

Adisasmita, Rahardjo. (2011). Pengelolaan Pemerintah dan Pendapatan Daerah .Yogyakarta: Graha Ilmu

Arikunto, Suharsimi. (2002). Prosedur Penelitian Suatu Pendekatan. Jakarta: Bina Aksara

Anggoro, Toha. (2008). Metode Penelitian

Kualitatif. Jakarta:Universit as Terbuka

Danim. Sudarwan. (2002). Menjadi Peneliti Kualitatif. Bandun: Pustaka Setia

Departemen Dalam Negeri. (2005). Instruksi Mentri Dalam Negeri Nomor 56 Tahun 2005 tentang Petunjuk Pelaksanaan Bantuan Pembangunan Desa. Jakarta.

Departemen Dalam Negeri. 2008. Instruksi Mentri Dalam Negeri Nomor 116 Tahun 2008 tentang Pedoman Umum Pengaturah Mengenai Desa. Jakarta.

Hatu, Rauf . (2010). Pemberdayaan dan Pendampingan Sosial
Masyarakat. Gorontalo: Jurnal inovasi

Juliantara, Dadang. (2000). Menggeser Pembangunan Memperkuat Rakyat. Yogyakarta: Lapera Pustaka Utama.

Mardikanto. (2012). Pemberdayaan Masyarakat dalam Perspektif Kebijakan Publik. Bandung: Alfabeta

Sugiyono. (2004). Metode Penelitian Administrasi. Bandung.: Alfa Beta.

Supriatna Tjahja. (2000). Strategi Pembangunan dan Kemiskinan. Jakarta: Rineke Cipta. 